\section{POLYVINYL ALCOHOL/SILICA/CLAY COMPOSITES: EFFECT OF CLAY ON SURFACE MORPHOLOGY AND THERMO-MECHANICAL PROPERTIES}

Article history

Received

13 April 2015

Received in revised form

15 June 2015

Accepted

15 December 2015

Josephine Chang Hui Laia*, Md. Rezaur Rahmana, Sinin Hamdan ${ }^{b}$

aDepartment of Chemical Engineering and Energy Sustainability, Faculty of Engineering, University Malaysia Sarawak, 94300 Kota Samarahan, Sarawak, Malaysia bDepartment of Mechanical and Manufacturing Engineering, Faculty of Engineering, University Malaysia Sarawak, 94300 Kota Samarahan, Sarawak, Malaysia

\section{*Corresponding author josephinelai91@hotmail.com}

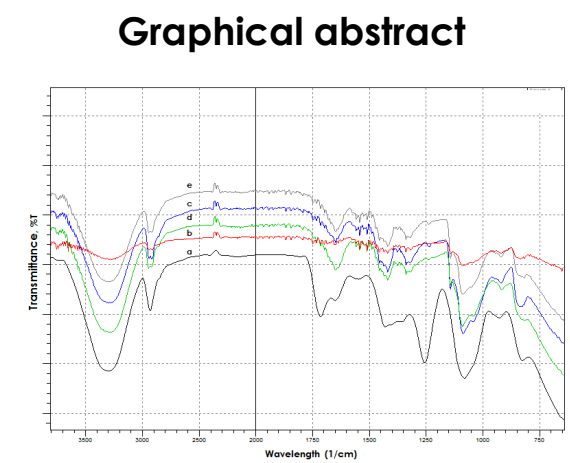

\begin{abstract}
A simplified route towards the synthesis of polyvinyl alcohol/silica/clay (PVA-SiO $2-c l a y)$ composites was presented. PVA-SiO 2 -clay composites were prepared via solution intercalation method. All the composites were characterized by Fourier Transform Infrared Spectroscopy (FT-IR), Scanning Electron Microscopy (SEM), adsorption isotherm (BET), X-ray fluorescence (XRF), tensile test and Thermogravimetric Analysis (TGA). FTIR spectrum indicated that PVA-SiO ${ }_{2}$-clay composites especially clay (1.28E) loaded composites had much less transmittance percentage compared to pure PVA and others clay composites. The SEM revealed that the interfacial bonding between $\mathrm{PVA}_{-} \mathrm{SiO}_{2}$ and clay (1.28E) was much better than others clay loaded composites which was reflected in adsorption isotherm. The BET result also showed high specific surface area with low diameter of pore size of the composites. The thermal stability of $\mathrm{PVA}-\mathrm{SiO}_{2}$-clay $(1.28 \mathrm{E})$ composites was the highest and it had higher activation energy due to the strong bonding between the trimethyl stearyl ammonium with both PVA$\mathrm{SiO}_{2}$. The XRF result showed that clay (1.28E) loaded composites contained significant high percentage of $\mathrm{Si}$ which confirmed the presence of Si-O-Si stretching vibration while the high percentage of $\mathrm{K}$ proved the clay mineral content in the composite. Clay (1.28E) enhanced the tensile strength and modulus of $\mathrm{PVA}_{-} \mathrm{SiO}_{2}$-clay composites among all the composites.
\end{abstract}

Keywords: Polyvinyl alcohol/silica/clay composites, FTIR, SEM, TGA, XRF, BET

\begin{abstract}
Abstrak
Satu laluan yang termudah untuk sintesis komposit polivinil alkohol/silika/tanah liat

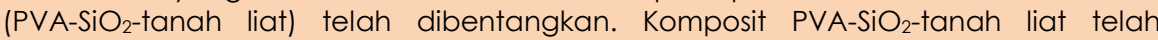
disediakan melalui kaedah penyelesaian interkalasi. Semua komposit telah disifatkan melalui Fourier Transform Infrared Spektroskopi (FT-IR), Mengimbas Mikroskopi Elektron (SEM), penjerapan isoterma (BET), sinar X pendarfluor (XRF), ujian tegangan dan Analisis Termogravimetri (TGA). Spektrum FTIR menunjukkan bahawa komposit PVA$\mathrm{SiO}_{2}$-tanah liat terutamanya komposit muatan tanah liat (1.28E) mempunyai kurang peratusan pemindahan berbanding dengan tulen PVA dan komposit muatan tanah liat yang lain. SEM mendedahkan bahawa ikatan antara $\mathrm{PVA}-\mathrm{SiO}_{2}$ dengan tanah liat (1.28E) adalah jauh lebih baik daripada komposit muatkan tanah liat yang lain seperti dicerminkan dalam penjerapan isoterma. Hasil BET juga menunjukkan bahawa
\end{abstract}

